\title{
Understanding unsuccessful attempts to quit smoking: a social phenomenology approach
}

\author{
Compreendendo o insucesso da tentativa de parar de \\ fumar: abordagem da fenomenologia social \\ Comprendiendo el fracaso del intento de dejar de \\ fumar: abordaje de la fenomenología social
}

Maria Cristina Pinto de Jesus ${ }^{1}$, Marcelo Henrique da Silva², Samara Macedo Cordeiro², Estela Kortchmar², Vanderleia Soeli de Barros Zampier², Miriam Aparecida Barbosa Merighi ${ }^{3}$

How to cite this article:

Jesus MCP, Silva MH, Cordeiro SM, Kortchmar E, Zampier VSB, Merighi MAB. Understanding unsuccessful attempts to quit smoking: a social phenomenology approach. Rev Esc Enferm USP. 2016;50(1):71-8. DOI: http://dx.doi.org/10.1590/S0080-623420160000100010

${ }^{1}$ Universidade Federal de Juiz de Fora, Faculdade de Enfermagem, Juiz de Fora, MG, Brazil.

${ }^{2}$ Universidade de São Paulo, Escola de Enfermagem, Programa de Pós Graduação em Enfermagem, São Paulo, SP, Brazil.

${ }^{3}$ Universidade de São Paulo, Escola de Enfermagem, Departamento de Enfermagem Materno-Infantil e Psiquiátrica, São Paulo, SP, Brazil.

\section{ABSTRACT}

Objective: The aim of this paper is to understand the experience of smokers in view of unsuccessful attempts to quit smoking. Method: This study is based on social phenomenology. Between November and December of 2014, nine interviews were conducted with people that had attempted to quit smoking. The content of these interviews was analyzed and discussed based on the related literature. Results: Unsuccessful attempts to quit smoking are related to tobacco addiction; cigarettes are seen as a support to cope with everyday stressful situations. Attempts to quit the smoking habits were based on the need of health improvement and insistence of family and friends. Smokers reported the use of habit cessation strategies learned in support groups, but they also express expectation of specialized psychological support. Conclusion: The study points out the need to expand the strategies of approaching smokers, and reinforcing psychological support in order to achieve success in the attempt to quit smoking.

\section{DESCRIPTORS}

Smoking; Smoking Cessation; Public Health Nursing; Qualitative Research. 


\section{INTRODUCTION}

Because tobacco addiction represents a public health problem, fighting the smoking habit has been increasingly addressed by public policies over the last years. According to the World Health Organization (WHO), it is the leading cause of preventable deaths in the world. It is estimated that one third of the world adult population consists of smokers, representing $47 \%$ of the male population and $12 \%$ of the female population ${ }^{(1)}$. In Brazilian capital cities the prevalence of tobacco addiction ranges between $12.9 \%$ and $25.2 \%$. The highest level of prevalence was found among people with low education levels and among men. Nearly 200,000 Brazilians die every year as a consequence of smoking ${ }^{(2)}$.

Concerns about damages to health and the shift of the social paradigm in relation to tobacco seen in recent decades have been inciting the Brazilian government to develop laws related to the creation of strategies for tobacco control, including measures to discourage the initial use and to promote the cessation of the habit. The actions for fighting tobacco addiction are part of the National Tobacco and Other Cancer Risk Factors Control Program ${ }^{(3)}$.

This program recommends that health professionals, especially those working in primary health care, use the cognitive-behavioral approach method in the treatment of smokers. This method consists of the combination of cognitive interventions with behavioral skills training; it may be associated with pharmacotherapy, substantially increasing the rate of success in attempts to quit smoking ${ }^{(4)}$. Despite the fact that current caring strategies include cognitive-behavioral approach and the use of drugs, the therapy does not guarantee that all attempts to quit smoking are successful.

International literature points out the high rates of attempts to quit tobacco addiction. An epidemiologic study conducted in Italy showed that about $40 \%$ of the totality of smokers made an attempt to quit smoking but only $8 \%$ were successful in the first attempt ${ }^{(5)}$. In the United States it was found that a significant part of the smokers would like to quit the addiction; nearly $50 \%$ have already attempted to quit smoking at least once along their lives but most of these attempts were not successful ${ }^{(6)}$.

In Brazil, a study comparing the use of tobacco between genders found that women presented higher percentages than men in the attempts to quit smoking ${ }^{(7)}$. Another study found that $42.1 \%$ of the smokers that made attempts to quit smoking had relapses at some point ${ }^{(8)}$.

The high number of attempts to quit smoking and the extremely low rate of success indicate a gap between the need to promote a reduction in tobacco use and the means available to achieve this goal ${ }^{(9)}$. Quitting tobacco may be a hard experience as the dependence includes a set of behavioral, cognitive, social, and physiologic phenomena that prevent most smokers from having a successful first attempt of quitting tobacco ${ }^{(1,5)}$.

At national and international levels, quantitative ${ }^{(5,7)}$ and qualitative ${ }^{(10-11)}$ investigations showed that attempting to quit smoking has been widely discussed by researchers in the area. However, in the reviewed qualitative studies there was a preference for the use of focus groups as the data collection technique. In this context, this phenomenological approach study is of paramount importance as it evidences the inter-subjective aspect implicit in the attempt of quit smoking and broadens the discussion on this important subject of public health.

The evidence produced in this study may contribute to a reflection on the approach and strategies of intervention used by health professionals, particularly nurses in the support to smokers attempting to quit the habit.

The aim of the present study is to understand the experience of smokers in view of unsuccessful attempts to quit smoking. To this end, the following questions guided this research: What contributes to the failure of an attempt to quit smoking? And What are the expectations of smokers after failing several times in the attempt to quit smoking?

\section{METHOD}

The Alfred Schütz's social phenomenology is used as the theoretical-methodological framework of this qualitative research. The focus of social phenomenology refers to the action of men in the world of life - scenery of social relations. The action of men in this world is guided by their biographic status - current situation consisting of a history settled by previous subjective experiences. This experience brings a wealth of knowledge that is available and accessible according to the biographic status. Such collection consists of information transmitted by parents, teachers, and experiences that structure its range of knowledge $\mathrm{e}^{(12)}$.

The biographic status and the range of knowledge available and accessible substantiate the projection of the action in the social world. This action is interpreted by the individual from existential reasons derived from their experiences inscribed in subjectivity and that consist in conductors of the action. Those based on antecedents, collection of knowledge, and experiences in the biopsychosocial sphere are called reasons why and those related to achievement of goals, expectations, and projects are called reasons for ${ }^{(12)}$.

In the present study, the social action refers to the attempt to quit smoking. The modern-day smoker lives in a world that restrains the use of tobacco and highlights the dangers of smoking. The knowledge acquired in the social environment as well as in the experiences with tobacco lead individuals to attempt to quit smoking.

This study was conducted in two Primary Health Care Units (PHCU) of a city in the Zona da Mata in the state of Minas Gerais that promote the creation of tobacco prevention and treatment groups in accordance with the guidelines of the National Tobacco and Other Cancer Risk Factors Control Program. The group meetings toke place on a bimonthly basis, conducted by the professionals of the units (social workers, nurses and physicians). The activities conducted in the group included structured sessions of cognitive-behavioral approach consisting of four monthly meetings, medical and nursing visits, distribution of specific drugs (Bupropion and nicotine replacement patches), and distribution of a participant's manual reinforcing the 
group discussions. In addition, there were maintenance sessions for those who successfully quit smoking.

For the selection of participants, the researchers visited the PHCU and contacted the nurses. The nurses provided lists with the telephone number of 30 smokers who participated in the activities of the tobacco prevention and treatment group but who did not quit smoking at the end of the fourth session. With the list of each PHCU, potential participants were contacted via telephone and invited to participate in the study.

Fifteen smokers agreed to participate. Of those, ten showed up for the interview. One of the testimonies was excluded as its content was not sufficient to meet the aims proposed for the study. Thus, nine individuals were included in the research (both male and female older than 18 years who agreed to voluntarily participate). They used the prescribed drug and participated in all the sessions of the group but achieved no success in attempting to quit smoking.

The testimonies were collected during November and December of 2014 through open interviews (with an average duration of 50 minutes) following the guiding questions: Tell us about your attempt to quit smoking. Considering that your attempt to quit smoking was unsuccessful, what are your plans now?

All participants were interviewed in a private room in the premises of the PHCU. They authorized the use of a voice recording device to record the full interview for further analysis. The objectives of the research were explained before the interview, which started after the participants signed a free and informed consent form. The testimonies of the participants revealed a convergence of meanings after the seventh interview, without the occurrence of new themes until the ninth testimony ${ }^{(13)}$. Thus, nine interviews were sufficient to achieve the goal and answer the guiding questions proposed in this study.

In order to ensure anonymity, the testimonies were identified by the letter I (Interview) and Arabic numbers corresponding to the order of the interviews, namely I1 to I9.

The organization and analysis of the results were based on the theoretical study of Alfred Schütz' social phenomenology $y^{(14)}$. After a perusal of the interviews the units of converging meanings (similar excerpts in the speeches) were grouped, allowing the composition of the study categories. Those were discussed in light of the literature related to the theme, having the adopted theoretical-methodological framework as the basic line of thinking.

This research was approved by the Human Research Ethics Committee of the Federal University of Juiz de Fora - UFJF, under the Legal Opinion 699.381, of June $24^{\text {th }} 2014$.

\section{RESULTS}

Eight participants were women, most of them married, with six years of schooling and average monthly income corresponding to the minimum wage. The average age was 46.85 years. Only one participant reported no diseases as- sociated with smoking; the others mentioned systemic arterial hypertension, diabetes mellitus, abnormal lipid levels, asthma, bronchitis, osteoporosis, breast cancer, and skin cancer. Eight individuals reported an undergoing treatment for symptoms of anxiety and depression with the use of antidepressants and antianxiety agents.

Smoking time ranged between 11 and 62 years; the average time was 37 years. Most initiated the tobacco use during adolescence (mean age was 13 years old). Seven participants reported smoking between 11 and 20 cigarettes per day. The mean number of attempts to quit smoking was seven times, ranging between 1 and 20 attempts. All the interviewees had tried at least one drug when attempting to quit the addiction, especially Bupropion that is associated with nicotine replacement patch therapy.

The categories Cigarettes calm me down, I'm addicted to cigarettes, I want to quit smoking because cigarettes are expensive and harm my health, and My family asks me to quit smoking reveal the everyday life of smokers who have made several unsuccessful attempts to quit (Reasons why). The category How to successfully quit smoking expresses the expectations of smokers after unsuccessful attempts to quit the addiction (Reasons for).

\section{Cigarettes Calm me DOWN}

Smokers justified the maintenance of the smoking habit based on the anxiety generated by the stress resulting from their everyday problems. Cigarettes are seen as a sedative agent, an outlet for coping with everyday stressful situations. Such situations contribute to fail attempts to quit smoking: (...) the everyday life (...) stress, problems that stop me from quitting smoking (I5).

I'm very stressed, very nervous (...) It seems that cigarettes are the only thing that calms me down (...) When I am about to have a nervous crisis I smoke a cigarette and I'm ok! It disappears! (I7).

I take it out on cigarettes, because I am anxious. It is hard for me to quit smoking (...) because it seems to be an outlet (...) It seems that without this I will get mad, crazy (I8).

Family conflicts were also mentioned by the participants as triggering factors of stress that motivates the maintenance of the smoking habit.

(...) family problems, problems with my son, I am very anxious. I am divorced, so I am both father and mother. (...) there is a burden on me, I am anxious to solve everything and do the best in relation to my son. (...) anything that affects my son makes me smoke more (I3).

(...) due to family problems I started smoking and never stopped. This is how I am, if I have a problem, I smoke. (...) my former daughter-in-law does not allow my son to see his son; this breaks me (I4).

Another issue reported by the interviewees relates to physical and psychological addiction as well as the association of behaviors that contribute to the fail attempts to quit smoking. 


\section{AM ADDICTED TO CIGARETTES}

Smokers acknowledge their addiction to nicotine and that the withdrawal symptoms hinder the achievement of success in their attempts of quitting tobacco:

At the first time I resisted for a whole day without smoking, but I had to go to the hospital due to shortness of breath, because I am addicted to that chemistry. The second attempt was when I was hospitalized (...) I was avid for a cigarette. These were my two attempts to quit smoking (I1).

(...) it seems to be ingrained in my blood (...) it is an unfortunate addiction (...) on Sunday I forgot to buy cigarettes, then on Monday I woke up and I wanted to smoke a cigarette; I was even blind, I was almost run over, I was sick, nervous (...) I smoked and calmed down like if I had taken a sedative (I7).

The participants point out smoking as a support for coping with the emotional problems of everyday life. This contributes to the high rate of unsuccessful attempts to quit smoking:

I feel a little lonely because a family consists of father, mother, and children; when we do not have a father I think we become a little weak (...) Because, as a matter of fact, I use cigarettes as an amulet that strengthens me, that helps me make more decisions (I3).

(...) it is funny, if I have a problem, I smoke a cigarette (...) it seems to give me the support I need to overcome the difficulties in life (...) cigarettes are my partners (...) they help me solve things, this is what I feel in a cigarette (...) I know it does not help me, that it is actually a problem, but from my perspective it helps me, so I smoke a cigarette (...) I relax (I4).

(...) we feel so lonely, then a cigarette seems to be a redemption, unfortunately (I7).

The association of behaviors between the daily activities and the smoking habit was also mentioned by the participants as a factor that hinders the attempts to quit smoking. I think the desire to smoke is in my head, it cannot be possible (...) I can avoid smoking during the whole afternoon, why do I smoke after meals? (...) I smoke four cigarettes: after breakfast, after lunch, after coffee break, and after dinner (...) I have to smoke, even half an hour later, I do smoke, there is no other way (I5).

\section{WANT TO QUIT SMOKING BECAUSE CIGARETTES ARE EXPENSIVE AND HARM MY HEALTH}

Smokers recognize the harmful effects of smoking, but despite the several attempts to get rid of the tobacco, they keep smoking:

(...) I try to quit smoking because I know it harms my health; I will make a new attempt, but I am not sure if one day I will succeed (...) I would really like to quit smoking in order to have a healthy life (...) I fear the consequences (...) I seek inspiration in people who successfully quit the habit, in how they did it, each one has his or her own way to get success (I3).

I want to stop smoking, coughing, undergoing a treatment, because there is something wrong with my lungs (...) it is chronic obstructive pulmonary disease (...) one of these days I was feeling tired, with dyspnea (...) it must be the cigarettes (I9).

Although they keep smoking, the high price of cigarettes was mentioned by the participants as a factor that encourages the attempts to get rid of the addiction:

(...) I intend to quit smoking because cigarettes are very expensive and bad for my health. (...) if we reflect about how much we spend on cigarettes we'll find out that we could do other things with that money (I5).

\section{My fAMILY ASKS ME TO QUIT SMOKING}

The participants report pressure from family as a reason for their attempts to quit smoking:

I raise my granddaughter, so I have to manage to quit smoking (...), because everyone says I have to stop... my daughter, my granddaughter, my wife (I1).

I promised to my grandson that I will quit smoking (...) I'll do this for him as a birthday present, I'll quit smoking. (...) He said 'grandma, I can't stand you smoking anymore, the smell of cigarettes' (...) (I4).

Oh, I keep trying as I can (...) I want to see my son happy. (...) so that my six-year-old son does not need to hug his mother with cigarette smell (...) (I8).

Reflecting on the reasons that prevent a successful cessation of tobacco use, in order to succeed in their next attempts smokers present as expectations following the guidance received and obtaining other therapies that were not included in the tobacco prevention and treatment group.

\section{How TO SUCCESSFULLY QUIT SMOKING}

Aiming at quitting smoking, the participants mention their desire to use the strategies learned in the group, such as a gradual reduction on the number of cigarettes per day and replacement of cigarettes with food or an activity:

I hope to manage to succeed, reducing the number of cigarettes; when I feel the desire to smoke I take something to eat; I want to gradually quit (I1).

(...) I will replace the cigarettes (...) plenty of water, carrots, everything to avoid smoking (...) I have already participated in tobacco groups, but I did not quit. (...) I don't know what else to do. (...) I have to keep trying, gradually reducing it, because I cannot quit at once. I hope to smoke less and less (I5).

Another aspect mentioned relates to their need for specialized psychological support allied to the tobacco prevention and treatment group:

(...) I think we should receive psychological assistance, and not just words: 'you cannot smoke, you must eat a carrot! Practice some physical activity when you want to smoke, take a deep breath', this does not help at all. A psychologist should be present to teach us how to deal with the addiction. The more you talk about cigarettes the more you want to smoke, so I think we should talk about the problems that lead us to smoke (...) the reason for the desire to smoke, what stresses you and makes you nervous, leading you to smoke (...) there should be a psychologist to talk with us (I2). 
Some participants reported the need to use other drugs in addition to those recommended by the National Tobacco and Other Cancer Risk Factors Control Program:

(...) I need another type of help. With only these prescribed drugs and attending the meetings we cannot quit smoking (...) (I2).

(...) I need another type of drug (...) the group was not sufficient (...) I have already participated in tobacco groups and I was not successful in quitting the habit. I have already used patches and Bupropion (...) I need some stronger drug (I4).

\section{DISCUSSION}

The indications expressed in the testimonies of the participants revealed barriers to quitting the smoking habit that refer to the scenario of the social action - the everyday world. Taking into account the challenges to be routinely faced within social relationships, the way smokers are biographically located in this world hinders the cessation of tobacco use. The life context experienced by smokers reveals the reasons that lead to failure in attempts to quit smoking (reasons why).

In the present study, the failure in attempting to quit smoking is related to the fact that cigarettes are seen as a support for coping with stressful situations resulting from everyday activities, including family relationships. These results were also evidenced by a study conducted with women in the city of Florianópolis, Santa Catarina, Brazil. That study points out that the maintenance of tobacco use was seemingly associated with pressures regarding being an adult, dealing with difficulties at work and family problems are common challenges in this stage of life. People tend to believe that cigarettes may calm them down and increase their self-confidence. In this context, the meaning given to the act of smoking is seen as a support for dealing with everyday life complications and undesired emotions ${ }^{(15)}$.

The participants of the present study reported that during the attempts to quit smoking they experienced symptoms of depression and/or anxiety. A study conducted in the Southern region of Brazil showed that $52.5 \%$ of women and $12.5 \%$ of men presented depression and $27.5 \%$ of women and $7.5 \%$ of men lived with symptoms of anxiety. These percentages reveal that such psychiatric comorbidities are important factors to be considered in the evaluation of smokers as these may be one of the causes of relapses and/ or failure in the attempts to quit smoking ${ }^{(16)}$.

Another aspect that increases the difficulty to quit tobacco use is nicotine addiction, consisting of two basic components: physical, represented by the intense desire to smoke and withdrawal symptoms; and psychological, represented by the meaning that people imply to cigarettes as being a support for coping with situations of loneliness, stress, and frustrations. Furthermore, it involves associations of behaviors such as smoking and drinking coffee, smoking and the use of alcohol, smoking after the meals, among others ${ }^{(17)}$.

The testimonies in the present study reveal the difficulty in dealing with nicotine withdrawal symptoms, psychological dependence, and behaviors associated with smoking. A study conducted with employees of a nursing school in the Southern region of Brazil showed convergence with these results, emphasizing that the nicotine addiction represents the most complicated factor hindering smoking cessation. The pleasure provided by smoking, emotional aspects, influence of other people, and the use of cigarettes as part of the daily routine was also pointed out $^{(8)}$. Another study conducted with groups of smokers in the city of Rio de Janeiro, Brazil, indicated that besides the chemical addiction smokers reported psychological dependency, expressed by the fact that they see cigarettes as partners ${ }^{(18)}$.

Despite the difficulties listed by smokers while attempting to quit the habit, they report a personal motivation to try to quit tobacco, particularly characterized by the awareness of the harmful effects of cigarettes on their health. On the other hand, pressure from family represents an extrinsic motivational factor that contributes to keep the smoker trying to quit the habit. As it is a habit that involves not only personal factors, social reasons and the social environment play a significant role in the acquisition, maintenance, and attempts to quit smoking ${ }^{(19)}$.

Similar results were found in a study conducted in Holland. Among the reasons that led smokers to try to quit the habit, the study mentions: concern about health problems associated with cigarettes, individual motivation, and influence of friends and family ${ }^{(10)}$. Witnessing the experiences of other people that suffered harms to their health due to the use of tobacco may influence the decision to quit the addiction $^{(15)}$. However, a study conducted in the Northern region of Portugal revealed that many people continued to smoke despite their negative perception on the consequences and risks associated with the use of tobacco ${ }^{(20)}$.

The motivation given by health professionals to smokers through information on the benefits of quitting smoking may be a strategy to motivate them to try to quit the habit ${ }^{(8)}$. In this sense, studies recommend the use of the argument that quitting tobacco will bring health benefits as an incentive in the prevention campaigns and approaches for smokers. Such allegation should be reinforced, even after the occurrence of a disease as a consequence of smoking ${ }^{(21)}$.

However, attempting to quit smoking presents some complexity and requires more than information about the harmful effects on health. A U.S. study corroborated this conclusion pointing out that emphasizing the dangers of smoking in health education activities for tobacco addicts seemingly does not achieve the goals in relation to the decision to quit smoking ${ }^{(22)}$.

The financial burden resulting from the purchase of cigarettes was also pointed out as a contributing factor to make people decide trying to quit the habit. These results are consistent with results of another study that also indicated the expenses arising from purchase of cigarettes as motivational themes to quit smoking, as well as the harmful effects on health resulting from the addiction ${ }^{(23)}$. On the 
other hand, taking into account the income of smokers, the price of cigarettes must be substantial to affect the motivation to quit the habit ${ }^{(11)}$.

Even aware of the personal and socioeconomic damages the individual maintains the habit of smoking, experiencing a situation of ambivalence between the pleasure provided by smoking and the desire to quit it. Considering motivation as a conscious inner state that encourages people to act $^{(12)}$, it is necessary to work this ambivalence evidenced by smokers that seek help but that are not always ready to quit smoking ${ }^{(21)}$.

The understanding of the context of life of the smokers in this study reveals that the attempts to get rid of tobacco addiction were mostly related to situations experienced in social relations, such as family relationships. Although meaningful people may inspire an attempt to cease the use of tobacco, smokers need to intensify their intrinsic motivation in order to achieve success in this action. The human action is conscious, intentional, endowed with purpose, and based on existential reasons. These presuppose a reflection on the life experiences (reason why) and the desire to promote changes (reasons for) ${ }^{(12)}$.

The expectations of smokers (reason for) after failed attempts reveal the desire to cease the habit in a gradual manner. It is important to point out that the strategy involving reduction in the number of cigarettes per day does not always result in a successful attempt; it may complicate the experience even more as in many cases it becomes a way to postpone the cessation instead of quitting ${ }^{(17)}$. A study conducted with a group of drivers and conductors addicted to tobacco in the city of Porto Alegre, Brazil, showed that those who opted for the abrupt cessation presented a higher rate of success in attempts to quit smoking than those that chose the gradual cessation method. After some time, smokers that chose the cigarettes reduction method returned to their old pattern of consumption ${ }^{(24)}$.

The prevention and treatment group for smokers provides an environment where people may find the support necessary to overcome the challenge of quitting the tobacco addiction, sharing experiences and difficulties ${ }^{(11,15)}$. However, in the present study the smokers considered the cognitive-behavioral approach and the drug therapy provided by the public health system as insufficient to achieve success in their treatment. Although they are followed up in group activities by professionals of the family health team, the fact that the participants expressed the need for specialized psychological support is a point to be considered.

A study conducted in the city of Cuiabá, Mato Grosso, Brazil, recommended the incorporation of psychologists and psychiatrists in the multidisciplinary team to follow up smokers that are too anxious or affected by other psychiatric disorders $^{(7)}$. The presence of these professionals enable a deeper approach on the psychosocial aspects involved in the everyday life of smokers that affect their attempt to quit smoking ${ }^{(25)}$. Moreover, such presence enables a comprehensive assessment valuing the subjectivity in order to prepare an appropriate individualized plan to meet the needs of the smoker. This could enhance the results of the cognitive-behavioral therapy used to help the cessation of smoking ${ }^{(7,25)}$.

In relation to the need for a drug therapy, a study conducted in the state of Paraná, Brazil, pointed out that the use of cognitive-behavioral technique alone has not favored the continuity on the treatment of smokers. More than half of the participants that concluded the fourth session of the treatment quit smoking successfully; of these, $83.3 \%$ needed drug therapy ${ }^{(26)}$.

This study points out the importance of the association of pharmacological and non-pharmacological methods for the success of the treatment of individuals that want to quit smoking. In addition to group activities, the complexity involving an attempt to quit smoking requires a unique approach to the smoker, considering the inclusion of specialized professionals to intervene in the psychic dimension involving the smoking habit.

\section{CONCLUSION}

The aim of the present study is to understand the experience of smokers in view of unsuccessful attempts to quit smoking. This understanding refers to the life context of the smoker, permeated by the tobacco addiction seen as a support for coping with stressful situations in the everyday life. Professionals working in primary health care should be conscious of this context as an impediment to stop smoking and seek partnerships in the health care network to help smokers to cope with such situations.

The study showed that the attempt to quit smoking was based on the need for health improvement, pressure from family and friends, and the high price of cigarettes. This evidence calls the attention of professionals on the need for interventions that reinforce self-motivation as a key element for quitting tobacco.

The study also evidenced the expectations of smokers to successfully quit the addiction based on the strategies learned in the tobacco group. Nonetheless, the need for a specialized psychological service is pointed out. These results show the importance of prevention and treatment groups for smokers in primary health care services; however, it suggests that the strategies used in these groups should be expanded in order to favor the access of individuals that want to quit smoking to specialized services of psychology and/or psychiatry.

The fact that this study was conducted with participants from a specific tobacco prevention and treatment group is pointed out as a limitation, as it does not allow the generalization of its results. However, the presented scientific evidence may contribute for the health professionals to reconsider strategies used with smokers in primary health care services.

In order to make the approach to smokers more efficient, further qualitative and interventional studies for individuals trying to quit smoking are suggested to enable health professionals to access a broader range of scientific evidence. 


\section{RESUMO}

Objetivo: Compreender a experiência de pessoas tabagistas frente ao insucesso da tentativa de parar de fumar. Método: Estudo fundamentado na fenomenologia social. Realizaram-se nove entrevistas abertas com os fumantes que tentaram cessar o hábito de fumar, em novembro e dezembro de 2014, cujo conteúdo foi analisado e discutido com base na literatura. Resultados: O insucesso da tentativa de parar de fumar relaciona-se à dependência do cigarro, visto como um suporte para o enfrentamento de situações estressantes do cotidiano. As tentativas de cessar o hábito foram alicerçadas na necessidade de melhoria da saúde e insistência de pessoas próximas. O fumante refere utilizar estratégias de cessação do hábito aprendidas no grupo de tabagismo, mas expressa a expectativa de apoio psicológico especializado. Conclusão: Evidencia-se a necessidade de ampliar as estratégias de abordagem ao fumante, reforçando o suporte psicológico com vistas à obtenção de êxito na tentativa de parar de fumar.

\section{DESCRITORES}

Hábito de Fumar; Abandono do Hábito de Fumar; Enfermagem em Saúde Pública; Pesquisa Qualitativa.

\section{RESUMEN}

Objetivo: Comprender la experiencia de personas tabaquistas ante el fracaso del intento de dejar de fumar. Método: Estudio fundado en la fenomenología social. Se llevaron a cabo nueve entrevistas abiertas con fumadores que intentaron cesar el hábito de fumar, en noviembre y diciembre de 2014, cuyo contenido fue analizado y discutido en base a la literatura. Resultados: El fracaso del intento de dejar de fumar se relaciona con la dependencia del tabaco, visto como un soporte para el enfrentamiento de situaciones estresantes del cotidiano. Los intentos de dejar el hábito fueron cimentados en la necesidad de mejoría de la salud e insistencia de personas próximas. El fumador relata utilizar las estrategias de cesación del hábito aprendidas en el grupo de tabaquismo, pero expresa la expectación de apoyo psicológico especializado. Conclusión: Se evidencia la necesidad de ampliar las estrategias de abordaje al fumador, reforzando el soporte psicológico con vistas a la obtención de éxito en el intento de dejar de fumar.

\section{DESCRIPTORES}

Hábito de Fumar; Cese del Tabaquismo; Enfermería en Salud Pública; Investigación Cualitativa.

\section{REFERENCES}

1. World Health Organization. WHO Report on the Global Tobacco Epidemic, 2013: enforcing bans on tobacco advertising, promotion and sponsorship [Internet]. Geneva; 2013 [cited 2015 Apr 13]. Available from: http://apps.who.int/iris/bitstream/10665/85380/1/9789241505871_ eng.pdf

2. Brasil. Ministério da Saúde; Secretaria de Vigilância em Saúde. Vigitel Brasil 2011: vigilância de fatores de risco e proteção para doenças crônicas por inquérito telefônico [Internet]. Brasília; 2012 [citado 2015 abr. 13]. Disponível em: http://bvsms.saude.gov.br/bvs/publicacoes/ vigitel_brasil_2011_fatores_risco_doencas_cronicas.pdf

3. Silva ST, Martins MC, Faria FR, Cotta RMM. Combating smoking in Brazil: the strategic importance of government actions. Ciênc Saúde Coletiva. 2014;19(2):539-52.

4. Brasil. Ministério da Saúde. Portaria n. 571, 5 de abril de 2013. Atualiza as diretrizes de cuidado à pessoa tabagista no âmbito da Rede de Atenção à Saúde das Pessoas com Doenças Crônicas do Sistema Único de Saúde (SUS) e dá outras providências [Internet]. Brasília; 2013 [citado 2015 abr. 13]. Disponível em: http://bvsms.saude.gov.br/bvs/saudelegis/gm/2013/prt0571_05_04_2013.html

5. D'Argenzio A, D'Argenio P, Ferrante G, Minardi V, Possenti V, Quarchioni E, et al. $40 \%$ of smokers try to stop smoking, only $8 \%$ succeed in. Epidemiol Prev. 2011;35(5-6):362.

6. Centers for Disease Control and Prevention (CDC). Quitting smoking among adults-United States, 2001-2010. MMWR Morb Mortal Wkly Rep. 2011;60(44):1513-9.

7. Pawlina MMC, Rondina RC, Espinosa MM, Botelho C. Anxiety and low motivational level associated with the failure in smoking cessation. J Bras Psiquiatr. 2014;63(2):113-20.

8. Ferreira SAL, Teixeira CC, Corrêa APA, Lucena AF, Echer IC. Motivos que contribuem para indivíduos de uma escola de nível superior tornarem-se ou não tabagistas. Rev Gaúcha Enferm. 2011;32(2):287-93.

9. Rafful C, García-Rodríguez O, Wang S, Secades-Villa R, Martínez-Ortega JM, Blanco C. Predictors of quit attempts and successful quit attempts in a nationally representative sample of smokers. Addict Behav. 2013;38(4):1920-3.

10. Bommelé J, Schoenmakers TM, Kleinjan M, van Straaten B, Wits E, Snelleman M, et al. Perceived pros and cons of smoking and quitting in hard-core smokers: a focus group study. BMC Public Health. 2014;14:175.

11. Uppal N, Shahab L, Britton J, Ratschen E. The forgotten smoker: a qualitative study of attitudes towards smoking, quitting, and tobacco control policies among continuing smokers. BMC Public Health. 2013;13:432.

12. Wagner HR, organizador. Sobre a fenomenologia e relações sociais: Alfred Schutz. Petrópolis: Vozes; 2012.

13. Fontanella BJB, Luchesi BM, Saidel MGB, Ricas J, Turato EB, Melo DG. Amostragem em pesquisas qualitativas: proposta de procedimentos para constatar saturação teórica. Cad Saúde Pública. 2011;27(2):388-94.

14. Jesus MCP, Capalbo C, Merighi MAB, Oliveira DM, Tocantins FR, Rodrigues BM, et al. The social phenomenology of Alfred Schutz and its contribution for nursing. Rev Esc Enferm USP. 2013;47(3):736-41.

15. Eckerdt NS, Corradi-Webster CM. Meanings about smoking for women participant in a group for smokers. Rev Latino Am Enferm. 2010;18(n.spe):641-7.

16. Zancan N, Colognese BT, Ghedini F, Both T. Intervenções psicológicas em grupos de controle de tabagismo: relato de experiência. Rev Psic IMED. 2011;I3(2):534-44. 
17. Brasil. Ministério da Saúde; Instituto Nacional de Câncer. Coordenação de Prevenção e Vigilância. Abordagem e tratamento do fumante: consenso 2001. Rio de Janeiro: INCA; 2001.

18. Nepomuceno TB, Romano VF. Tabagismo e relações de poder na produção da saúde. Saude Soc. 2014;23(2):701-10.

19. Robson N, Bond A, Wolff K. A comparison of smoking behaviour characteristics between Caucasian smokers in the United Kingdom and Malay smokers in Malaysia. Prev Med. 2013;57 Suppl:S8-10.

20. Afonso F, Pereira MG. Preditores da dependência nicotínica e do comportamento planeado para deixar de fumar. Aná Psicológica (Lisboa). 2013;31(1):17-29.

21. Russo AC, Azevedo RCS. Factors that motivate smokers to seek outpatient smoking cessation treatment at a university general hospital. J Bras Pneumol. 2010;36(5):603-11.

22. Stewart DW, Adams CE, Cano MA, Correa-Fernández V, Li Y, Waters AJ, et al. Associations between health literacy and established predictors of smoking cessation. Am J Public Health. 2013;103(7):43-9.

23. Rosenthal L, Carroll-Scott A, Earnshaw VA, Sackey N, O'Malley SS, Santilli A, et al. Targeting cessation: understanding barriers and motivations to quitting among urban adult daily tobacco smokers. Addict Behav. 2013;38(3):1639-42.

24. Lopes FM, Peuker AC, Bizarro L. Aplicação de um programa de cessação do tabagismo com rodoviários urbanos. Psicol Cienc Prof. 2013;33(2):490-9.

25. Seabra CR, Faria HMC, Santos FR. O tabagismo em uma perspectiva biopsicossocial: panorama atual e intervenções interdisciplinar. CES Rev. 2011;25:321-36.

26. Meier DAP, Vannuchi MTO, Secco IAO. Abandono do tratamento do tabagismo em programa de município do norte do Paraná. Rev Esp Saúde. 2011;13(1):35-44. 